\title{
Quantification of household waste diversion from landfill disposal by waste management practices
}

\author{
O. Mitaftsi \& S. R. Smith \\ Centre for Environmental Control and Waste Management, \\ Civil and Environmental Engineering, Imperial College, London, UK
}

\begin{abstract}
The European Landfill Directive requires the phased reduction of biodegradable waste disposal to landfill. One option, with significant potential to divert biodegradable municipal waste from landfill, is to encourage householders to compost their organic waste at home and this approach is supported in principle by the UK Government. However, whilst the benefits of home composting are recognized, there is uncertainty about the actual quantitative effectiveness of this approach to biodegradable waste management and, currently, Local Authorities responsible for municipal waste disposal and recycling do not receive credit or recognition for promoting this activity in the UK. This project aims to quantify the amounts of waste diverted from landfill through home composting, and other household waste recycling methods, by measuring the effects of these practices on the quantity and composition of residual waste produced at the individual household level. An automatic weighing system was fitted to a refuse collection vehicle (RCV) to provide data on the waste arisings from 324 households in the urban Borough of Runnymede, West London. The households were allocated into four groups according to the waste management practices: home composting; home composting + kerbside recycling, kerbside recycling only and a control group who did not compost or participate in the kerbside recycling scheme. The RCV weight data were complemented by a detailed compositional analysis of residual waste collected from the households. This paper presents a summary and overview of the key results and outputs from the research programme.
\end{abstract}

Keywords: home composting, biodegradable waste, recycling, kerbside collection, landfill diversion, municipal solid waste. 


\section{Introduction}

One of the major issues associated with waste management in the UK is the reliance upon landfill for disposal of household waste. Landfill has become the dominant waste management route [1] because the geological and hydrogeological conditions have favoured the development of landfill sites at low cost. The continued predominance of landfill in current UK waste management practice reflects the fact that it remains the most adaptable and least expensive option in most geographical areas of the country [2].

However, landfill disposal of household waste is no longer regarded as an environmentally sustainable option [3] due to the environmental impacts arising from the high biodegradable organic content of domestic refuse. Household waste contains approximately $60 \%$ of biodegradable material [4], which generates landfill gas and leachate. Approximately 25.4 million tonnes of household waste were generated in 2003/04 in England, of which 4.5 million tonnes $(18 \%)$ were collected for recycling through kerbside collection schemes or deposited at civic amenity and bring sites, and the residual 20.9 million tonnes $(82 \%)$ were landfilled [5].

As with other Member States of the European Union, the UK is required to comply with the mandatory targets established by the Landfill Directive $(1999 / 31 / \mathrm{EC})$, to ultimately reduce biodegradable municipal waste (BMW) disposal in landfills to $35 \%$ of that produced in 1995 [6]. To assist in complying with these requirements, the Government and National Assembly in England and Wales published the 'Waste Strategy 2000' that established targets to recover at least $30 \%$ of household waste through recycling and composting by 2010 , increasing to at least 33\% by 2015 [7]. The Government's Strategy Unit report emphasized the importance of the role of home composting in diverting household waste from landfill disposal.

Composting is a natural aerobic biochemical process capable of converting biodegradable waste into a beneficial residue termed compost. Home composting is a simple, rewarding way to recycle garden and kitchen waste at home and creates a valuable soil amendment for gardens and lawns. It requires householders to separate and compost their own kitchen and garden waste in compost bins or traditional composting heaps. By composting at home, the cost and environmental risks of managing solid waste materials is reduced. Kitchen and garden waste, such as leaves, grass clippings, garden debris, and small branches, typically make up $27 \%$ of household waste [8]. When treated as waste, these materials increase the cost of collection and handling municipal solid waste (MSW). In landfill, they occupy valuable space and create potential pollutants.

Whilst the environmental and economic benefits of home composting are widely recognized, there is uncertainty and insufficient evidence regarding the actual contribution of small scale home composting systems at diverting the biodegradable fraction of household waste from landfill disposal. Under the current recycling credit scheme (RCS), waste collection authorities (WCAs) receive the saving in disposal costs by waste disposal authorities (WDAs) for diverted recyclable materials to motivate recycling of household waste [9]. 
However, due to the uncertainty about the value of home composting and the problems associated with measuring its positive influence on biodegradable waste reduction, the UK Government has not considered home composting as a practice to be rewarded in the current or revised RCS [10].

Jasim [11] recently monitored the amounts of biodegradable garden, food and paper waste deposited into home compost bins by a group of 64 homeowners for a period of two years in the suburban area of Runnymede Borough Council (RBC), West London. On average, approximately $400 \mathrm{~kg}$ of biodegradable waste were deposited annually per household into the compost bins and, if this amount equated directly to waste diversion from landfill disposal, it would correspond to $10 \%$ of the total quantity of waste arisings from door-to-door collection (this assumes a participation rate of $20 \%$ of households engage in home composting within the community).

This research project aims to further examine the impact of home composting activities on waste disposal. No direct measurements are available of the actual amounts of BMW diverted from landfill disposal by home composting. Therefore, this project adopted an innovative approach to measure waste diversion rates directly using a dynamic, automatic weighing system for individual refuse bins. The effects of kerbside recycling on residual waste disposal were also assessed.

\section{Materials and methods}

\subsection{Quantitative waste diversion assessment}

The impacts of home composting and kerbside recycling on landfill disposal of household waste were quantified by a novel research approach using an advanced weighing technology (SULO MGB Ltd, High Wycombe, UK) to directly measure residual waste arisings from individual households in the Borough of Runnymede, West London. The kerbside recycling scheme included the weekly collection of paper, cardboard, glass and steel and aluminium cans in the Borough. The wheeled bins of households participating in the monitoring programme were fitted with a passive read/write microchip to uniquely recognize the characteristics of each property. The weighing system is fitted to the mechanical lifter of the refuse collection vehicle (RCV) and weighs the containers before and after emptying providing an accurate measure of the net weight of the waste. An antenna on the RCV identifies the microchip and transmits the household identification information to the vehicle's on board computer. The weight data are stored on a RAM card, which is transferred to an office computer for data manipulation.

Information regarding the waste measurement practices of individual households in the Study Area on an established waste collection round, that was the focus of the previous research in the Borough by Jasim [11], was obtained from databases of properties that either: (a) had received at least one compost bin distributed by the RBC home composting scheme, and/or (b) were involved in 
the Council's kerbside recycling scheme. This initial screening identified approximately 450 potential properties in the Study Area for possible inclusion in the residual waste monitoring programme. These properties were further examined to confirm their involvement in home composting and/or kerbside collection or that they did not take part in either activity. Following this process, households that agreed to participate were selected and allocated into four treatment groups as follows:

1. - Recycling bin, - Compost bin ('Control' treatment group): 47 households;

2. + Recycling bin, - Compost bin ('Recycling only' treatment group): 92 households;

3. + Recycling bin, + Compost bin ('Recycling and composting' treatment group): 166 households;

4. - Recycling bin, + Compost bin (Composting only treatment group): 19 households.

Total number of households $=324$.

\subsection{Waste compositional analysis}

Compositional analysis of the residual waste from selected households in the treatment groups was undertaken with assistance of a specialist contractor (Waste Research Ltd, Sheffield, UK), following a standard waste categorization procedure [12]. This involved collecting the entire contents of the wheeled bin from each household and dividing the waste into 13 primary categories and 49 subcategories. Waste samples were collected on two occasions, during the summer (30 June 2004) and autumn (10 - 11 November 2004) periods, to assess seasonal trends in household waste disposal. The compositional analysis determined the total quantity of waste generated weekly by households in each treatment group, the range of materials present in the waste, the amount and relative proportions of these materials, and the quantity of waste that was potentially recyclable or compostable. Table 1 summarises the number of households that were sampled in the waste analysis programme. Households from all treatment groups participated in the summer waste analysis, whereas the 'Composting only' group was excluded in the autumn due to the small number of households in the Study Area that only composted their waste, and because the size of the 'Control' group was increased in the second phase of sampling.

Table 1: Number of households sampled in each treatment group for waste compositional analysis.

\begin{tabular}{lcc}
\hline \multirow{2}{*}{ Treatment Group } & \multicolumn{2}{c}{ No. of households } \\
\cline { 2 - 3 } & Summer & Autumn \\
\hline Control & 17 & 44 \\
Recycling only & 50 & 50 \\
Recycling and composting & 37 & 48 \\
Composting only & 12 & Not sampled \\
\hline Total & $\mathbf{1 1 6}$ & $\mathbf{1 4 2}$ \\
\hline
\end{tabular}




\section{Results and discussion}

\subsection{Quantitative waste diversion assessment}

The general trend in waste generation associated with each of the treatment groups was illustrated by weight data collected by the RCV weighing system in two consecutive weeks in October 2005. The average amount of household waste produced by the treatment groups in the Study Area remained below the national average of $23.1 \mathrm{~kg} /$ property/wk [5]. Table 2 presents the total number of properties which were serviced on both waste collection days per treatment group, the total number of persons living in the properties and the weight of residual waste deposited in the wheeled bins. The weekly average amounts of waste produced per property and per person are also given. The average occupancy was 3 persons/household. The effect of household occupancy and other socio-economic and demographic factors on waste production will be part of a more detailed statistical examination of the data, but are not considered further in this paper.

Households in the 'Control' group, that do not compost their waste or participate in kerbside collections, produced approximately $18 \mathrm{~kg} / \mathrm{wk}$ of residual waste. However, properties in the 'Recycling only' group also produced similar or slightly larger amounts of residual waste compared to the 'Control'. This could be explained if, for example, 'Recycling only' households did not actually participate in the kerbside recycling scheme in practice. Alternatively, recyclable materials may be separated by these households, but the spare capacity created by recovering the recyclables is filled with other waste materials, such as surplus bulky garden waste. By comparison, 'Composting only' households produced approximately $1-2 \mathrm{~kg}(6-9 \%)$ less waste than the 'Control' group. Homeowners would presumably dispose of all of their dry (i.e. non-biodegradable) waste first, therefore the observed reduction in the mass of collected waste for this group may reflect a direct consequence of home composting on biodegradable waste diversion. Alternatively, if homeowners in the 'Composting only' group behave in a similar way to the 'Recycling only' group and use the spare capacity in the bin to dispose of bulky garden waste (e.g. for material that may be unsuitable for home composting, for instance), the apparent reduction in residual waste may be explained because denser food waste removed from the residual waste by home composting may be replaced with surplus bulky waste of lower density. These results emphasize the importance of waste compositional analysis data to interpret the effects of recycled and home composting practices on residual waste collection. In contrast to either recycling or composting separately, households that both recycled and composted their waste had a much greater influence on landfill diversion by reducing the average amount of residual waste collected by approximately 3-5 kg (17-25\%) compared to the 'Control' group. Monitoring of residual waste collections from the households in the different treatment groups by the automatic RCV system is ongoing and will continue during the winter period 2005/06, and spring and summer periods 2006. 
Table 2: $\quad$ RCV residual weight data collected in two consecutive weeks.

\begin{tabular}{|c|c|c|c|c|c|c|}
\hline $\begin{array}{c}\text { Collection } \\
\text { period }\end{array}$ & Treatment group & $\begin{array}{c}\text { Total } \\
\text { no. of } \\
\text { properties }\end{array}$ & $\begin{array}{c}\text { Total } \\
\text { no. of } \\
\text { persons }\end{array}$ & $\begin{array}{c}\text { Total } \\
\text { waste } \\
(\mathrm{kg})\end{array}$ & $\begin{array}{c}\text { Average } \\
\text { waste } \\
\text { (kg/property) }\end{array}$ & $\begin{array}{c}\text { Average } \\
\text { waste } \\
\text { (kg/person) } \\
\end{array}$ \\
\hline \multirow{4}{*}{$\begin{array}{c}1^{\text {st }} \text { week } \\
11-13 \text { Oct } \\
2005\end{array}$} & Control & 31 & 93 & 580 & 18.71 & 6.24 \\
\hline & Recycling only & 81 & 207 & 1550 & 19.14 & 7.38 \\
\hline & Composting only & 15 & 45 & 255 & 17.00 & 5.80 \\
\hline & Recycling\&composting & 148 & 400 & 2069 & 13.98 & 5.24 \\
\hline \multirow{4}{*}{$\begin{array}{l}2^{\text {nd }} \text { week } \\
18-20 \text { Oct } \\
2005\end{array}$} & Control & 30 & 80 & 525 & 17.50 & 6.25 \\
\hline & Recycling only & 81 & 210 & 1484 & 18.32 & 6.72 \\
\hline & Composting only & 16 & 44 & 263 & 16.44 & 6.20 \\
\hline & Recycling\&composting & 148 & 399 & 2141 & 14.47 & 5.43 \\
\hline \multirow{4}{*}{$\begin{array}{c}\text { Mean of } \\
1^{\text {st }} \& 2^{\text {nd }} \\
\text { weeks }\end{array}$} & Control & 61 & 173 & 1105 & 18.11 & 6.39 \\
\hline & Recycling only & 162 & 417 & 3034 & 18.73 & 7.28 \\
\hline & Composting only & 31 & 89 & 518 & 16.71 & 5.82 \\
\hline & Recycling\&composting & 296 & 799 & 4210 & 14.22 & 5.27 \\
\hline
\end{tabular}

\subsection{Waste compositional analysis}

Table 3 shows the average amounts of total residual waste, and of ten major waste categories, deposited in the wheeled bins for the sampling periods in June and November 2004. The relatively low total value recorded for the 'Control' in the summer period, equivalent to $12.43 \mathrm{~kg} / \mathrm{property} / \mathrm{wk}$, may reflect the small number of properties included in the treatment group on this sampling occasion. During the summer, 'Recycling only' households disposed of the greatest quantity of residual waste overall, equivalent to $16.72 \mathrm{~kg} /$ property $/ \mathrm{wk}$, followed by the 'Composting only' group, which deposited $14.68 \mathrm{~kg} / \mathrm{property} / \mathrm{wk}$ in the wheeled bin for collection. However, in the autumn, the largest amount of residual waste was recorded for the 'Control' group, equivalent to $15.37 \mathrm{~kg} / \mathrm{property} / \mathrm{wk}$ and also a similar amount of residual waste, $15.10 \mathrm{~kg} /$ property/wk, was produced by the 'Recycling only' group at that time. At both sampling times, households involved in recycling and composting together disposed of much smaller amounts of waste overall, equivalent to $14.02 \mathrm{~kg} /$ property $/ \mathrm{wk}$ in the summer and $10.78 \mathrm{~kg} /$ property $/ \mathrm{wk}$ in the autumn, compared to the other treatment groups, consistent with the RCV data. Table 4 shows that the patterns in residual waste measured during autumn by the RCV system and from the waste compositional analysis were broadly similar except the amounts had apparently increased by 3-4 kg in October 2005 (RCV) compared to November 2004 (compositional data). This could reflect a general underlying rise in the total amount of residual waste produced between 2004 and 2005 and also differences in the actual properties sampled on the two occasions.

Putrescibles were the predominant waste type in all treatment groups in both the summer and autumn phases of the waste analysis. However, as may be expected, more putrescible waste was collected during the summer compared to the autumn period, reflecting the greater production of garden waste during the active growing season. The results showed that putrescible waste governed the overall waste arisings and, therefore, properties disposing of large quantities of 
biodegradable waste generated the largest amounts of residual waste. Putrescible waste was sorted into five subcategories and the amounts of these constituents in the residual waste are shown in Table 5.

Table 3: Average waste arisings (kg/property/wk) for the household treatment groups.

\begin{tabular}{|c|c|c|c|c|c|c|c|}
\hline \multirow[t]{2}{*}{ Waste fraction } & \multicolumn{2}{|c|}{ Control } & \multicolumn{2}{|c|}{ Recycling only } & \multirow{2}{*}{$\begin{array}{c}\begin{array}{c}\text { Composting } \\
\text { only }\end{array} \\
\text { Summer } \\
\end{array}$} & \multicolumn{2}{|c|}{$\begin{array}{c}\text { Recycling } \\
\text { \& composting } \\
\end{array}$} \\
\hline & Summer & Autumn & Summer & Autumn & & Summer & Autumn \\
\hline $\begin{array}{l}\text { Recyclable } \\
\text { materials }\end{array}$ & 3.62 & 5.32 & 4.20 & 3.94 & 3.99 & 2.87 & 2.40 \\
\hline Putrescibles & 6.31 & 5.81 & 8.83 & 7.27 & 7.26 & 6.70 & 5.01 \\
\hline $\begin{array}{c}\text { Paper\&card } \\
\text { (non recyclable) }\end{array}$ & 0.40 & 0.65 & 0.36 & 0.55 & 0.44 & 0.54 & 0.49 \\
\hline Plastic Film & 0.49 & 0.50 & 0.59 & 0.55 & 0.66 & 0.55 & 0.43 \\
\hline $\begin{array}{l}\text { Dense Plastic } \\
\text { Miscellaneous }\end{array}$ & 0.84 & 0.96 & 1.14 & 0.91 & 0.81 & 0.94 & 0.75 \\
\hline $\begin{array}{l}\text { Combustible } \\
\text { Non- }\end{array}$ & 0.60 & 1.40 & 1.14 & 1.30 & 1.15 & 0.75 & 1.06 \\
\hline Combustible & 0.01 & 0.08 & 0.19 & 0.38 & 0.18 & 1.27 & 0.24 \\
\hline HHW* & 0.05 & 0.24 & 0.02 & 0.05 & 0.01 & 0.09 & 0.06 \\
\hline WEEE** & 0.02 & 0.24 & 0.04 & 0.01 & 0.02 & 0.15 & 0.17 \\
\hline Fines & 0.09 & 0.17 & 0.21 & 0.14 & 0.16 & 0.16 & 0.17 \\
\hline $\begin{array}{c}\text { Total } \\
\mathrm{kg} / \text { property/wk }\end{array}$ & 12.43 & 15.37 & 16.72 & 15.10 & 14.68 & 14.02 & 10.78 \\
\hline
\end{tabular}

Note: Recyclable materials refer to the materials that are currently collected in RBC's kerbside collections. These are recyclable paper and card, glass, ferrous and non-ferrous metals and textiles. *Household Hazardous Waste ** Waste Electrical and Electronic Equipment.

Table 4: Comparison between total residual waste data measured by the RCV system and from the compositional analysis results.

\begin{tabular}{lcc}
\hline & \multicolumn{2}{c}{ Total waste generation (kg/property/wk) } \\
\cline { 2 - 3 } Treatment group & \multicolumn{2}{c}{ (no. of properties indicated in brackets) } \\
\cline { 2 - 3 } & $\begin{array}{c}\text { RCV weight data } \\
\text { (October 2005) }\end{array}$ & $\begin{array}{c}\text { Waste compositional analysis } \\
\text { (November 2004) }\end{array}$ \\
\hline Control & $18.11(31)$ & $15.38(44)$ \\
Recycling only & $18.73(81)$ & $15.09(50)$ \\
Recycling and composting & $14.22(148)$ & $10.78(48)$ \\
\hline
\end{tabular}

Garden waste constituted the majority of the putrescible waste in all waste samples. It was also the component which varied to the greatest extent between the summer and autumn sampling periods compared to other types of putrescible waste. Contrary to what might be anticipated, the amount of garden waste collected for disposal was increased by home composting compared to the 'Control' and 'Recycling only' groups. In the autumn, for example, the amount of garden waste disposed by the 'Recycling and composting' group increased by $44 \%$ compared to the 'Control'. Nevertheless, home composting reduced the total amount of putrescible waste overall because less kitchen waste was deposited in the wheeled bin for collection. The RCV data indicated that waste 
substitution could explain the similar overall waste arisings obtained for the 'Control' and 'Recycling only' groups (Table 2). This was confirmed by the compositional analysis, which showed that fewer recyclables were deposited in the residual waste by the 'Recycling only' group, but this was substituted by the increased disposal of garden and other putrescible waste, compared to the 'Control'.

Table 5: $\quad$ Putrescible waste arisings ( $\mathrm{kg} /$ property/wk) per treatment group.

\begin{tabular}{cccccccc}
\hline \multirow{2}{*}{$\begin{array}{c}\text { Putrescible } \\
\text { waste }\end{array}$} & \multicolumn{2}{c}{ Control } & \multicolumn{2}{c}{ Recycling only } & $\begin{array}{c}\text { Composting } \\
\text { only }\end{array}$ & \multicolumn{2}{c}{$\begin{array}{c}\text { Recycling \& } \\
\text { composting }\end{array}$} \\
\cline { 2 - 8 } & Summer & Autumn & Summer & Autumn & Summer & Summer & Autumn \\
\hline $\begin{array}{c}\text { Kitchen } \\
\text { compostable }\end{array}$ & 1.59 & 1.77 & 2.20 & 2.03 & 1.28 & 1.07 & 1.34 \\
$\begin{array}{c}\text { Kitchen non } \\
\text { compostable }\end{array}$ & 1.56 & 2.17 & 1.99 & 2.22 & 1.33 & 1.10 & 1.21 \\
$\begin{array}{c}\text { Liquids } \\
\text { Garden waste }\end{array}$ & 0.21 & 0.15 & 0.17 & 0.18 & 0.01 & 0.46 & 0.01 \\
$\begin{array}{c}\text { Other } \\
\text { putrescibles }\end{array}$ & 2.38 & 1.60 & 3.66 & 2.05 & 4.59 & 3.72 & 2.31 \\
\hline $\mathbf{k g}$ property/wk & 0.57 & 0.12 & 0.81 & 0.79 & 0.05 & 0.35 & 0.14 \\
\hline
\end{tabular}

The second dominant type of residual waste was the recyclable material not recovered by recycling. Recyclable materials were reduced in the residual waste from households participating in the kerbside recycling scheme compared to the 'Control' group (Table 6). The 'Recycling and composting' group performed better than the 'Recycling only' group regarding the amount of recyclable materials that were removed from the residual waste and therefore appeared to be the most highly motivated and conscientious recyclers of all the household groups examined. Paper and card is generally the most captured material in kerbside collections at the national level [5]. Nevertheless, recyclable paper and card represented the largest fraction of recyclables in the residual waste for all the household groups. Residual waste from 'Control' households in autumn contained the highest quantity of paper and card, equivalent to 3.52 $\mathrm{kg} /$ property/wk, whereas the 'Recycling and composting' households produced the smallest amount, equivalent to $1.64 \mathrm{~kg} / \mathrm{property} / \mathrm{wk}$. Glass was the next dominant recyclable material and the amount of residual glass disposed of in the wheeled bins was in the range 0.5 to $1 \mathrm{~kg} / \mathrm{property} / \mathrm{wk}$. The 'Recycling and composting' group were also the most effective recyclers of glass removing $78 \%$ and $60 \%$ of the glass disposed by the 'Control' and 'Recycling only' groups in the autumn, respectively. Ferrous and non-ferrous metals represented the smallest mass compared to other types of recyclable material and, in all cases, did not exceed $0.3 \mathrm{~kg} /$ property/wk in the residual waste. The 'Recycling and composting' properties recycled most of their metal waste and, in autumn $81 \%$ and $70 \%$ of metal waste was recovered for recycling by this group compared to the amounts disposed by the 'Control' and 'Recycling only' properties, respectively. 
According to Parfitt [8] households with large capacity wheeled bins generally take less material to civic amenity (CA) sites for disposal. These results go further and also demonstrate that material recovered from the residual waste collection by home composting and kerbside recycling may be substituted by other surplus garden waste; this type of material is likely to include low density woody clippings and prunings that are unsuitable for home composting.

Table 6: Recyclable material arisings ( $\mathrm{kg} / \mathrm{property} / \mathrm{wk})$ in residual waste from the treatment groups.

\begin{tabular}{lccccccc}
\hline \multirow{2}{*}{$\begin{array}{l}\text { Recyclable } \\
\text { material }\end{array}$} & \multicolumn{2}{c}{ Control } & \multicolumn{2}{c}{ Recycling only } & $\begin{array}{c}\text { Composting } \\
\text { only }\end{array}$ & \multicolumn{2}{c}{$\begin{array}{c}\text { Recycling } \\
\text { \& composting }\end{array}$} \\
\cline { 2 - 8 } & Summer & Autumn & Summer & Autumn & Summer & Summer & Autumn \\
\hline Paper \& card & 2.37 & 3.52 & 2.57 & 2.56 & 2.61 & 2.29 & 1.64 \\
Glass & 0.58 & 0.90 & 0.70 & 0.50 & 0.98 & 0.16 & 0.20 \\
Fe metals & 0.22 & 0.27 & 0.16 & 0.21 & 0.17 & 0.11 & 0.06 \\
Non-Fe metals & 0.08 & 0.10 & 0.06 & 0.02 & 0.06 & 0.01 & 0.01 \\
\hline kg/property/wk & 3.25 & 4.79 & 3.49 & 3.29 & 3.82 & 2.57 & 1.91 \\
\hline
\end{tabular}

\section{Conclusions}

The principal conclusions of this paper are:

- Households that practice both home composting and recycling may reduce the amount of residual waste collected for landfill disposal by approximately $20 \%$ compared to households which do neither activity.

- Putrescible matter was the predominant waste type in the residual waste and had an important influence on overall waste arisings. Waste production was greater in the summer compared to the autumn period due to larger quantities of biodegradable garden waste disposed in the summer season.

- Households that composted putrescible waste disposed of more garden waste in the wheeled bin than either 'Recycling only' or 'Control' households. This may be attributed to substitution with noncompostable, bulky garden waste which would otherwise be transferred to a CA site. However, overall putrescible waste arisings were smaller for the 'Recycling and composting' group because of reduced kitchen waste disposal.

- Waste from households involved in kerbside collection contained less recyclable material than households in the 'Control' group, but the total amount of residual waste was similar to the 'Control'. This was because recyclable materials were substituted by surplus putrescible waste in the wheeled bin.

- Households engaged in recycling and composting were the most effective and conscientious recyclers overall compared to the other household groups. 
- This research has demonstrated that home composting combined with kerbside collection of recyclable materials is effective in reducing the amount of residual biodegradable waste and the total amount of household waste collected for landfill disposal. Kerbside recycling must be coupled to other initiatives to reduce the amount of putrescible waste deposited in the residual waste bin, otherwise it may have little or no effect on the total quantity of household waste and can increase the amount of biodegradable waste collected for disposal.

\section{References}

[1] Department of Environment, Food and Rural Affairs (DEFRA), Municipal Waste Management Survey 2002/03, London, 2004.

[2] Neil P.A., Waste management-The essential service. Proc. of 'Options for Urban Waste Management in the $21^{\text {st }}$ century'. Imperial College London: London, 1997.

[3] Royal Commission of Environmental Pollution (RCEP), $17^{\text {th }}$ Report, Incineration of Waste, HMSO, London, 1993.

[4] Parfitt J. \& Flowerdew R., Methodological problems in the generation of household waste statistics: An analysis for the United Kingdom's National Household Waste Analysis Programme. Applied Geography, 17(3), pp. 231-244, 1997.

[5] Department of Environment, Food and Rural Affairs (DEFRA), Municipal Waste Management Statistics 2003/04, London, 2005.

[6] European Council (EC), EU Directives 99/31/EC on the landfill of waste, Off. J. Eur. Communities L182:1-19, 1999.

[7] Strategy Unit, Waste not Want not: a Strategy for dealing with the waste problem in England, London, 2002.

[8] Parfitt J., Analysis of household waste composition and factors driving waste increases, WRAP, UK, 2002.

[9] Department of Environment, Food and Rural Affairs (DEFRA), Municipal Waste Management 1996/97 and 1997/98, London, 2000.

[10] Department of Environment, Food and Rural Affairs (DEFRA), Draft Guidance on the Recycling Credit Scheme, London, 2006.

[11] Jasim S., The practicability of home composting for the management of biodegradable domestic solid waste, $\mathrm{PhD}$ Thesis, Imperial College London, 2003.

[12] AEA Technology (AEAT), MEL Research Ltd, Waste Research Ltd \& WRc, The Composition of Municipal Solid Waste in Wales, A report produced for the Welsh Assembly Government, UK, 2003. 